\title{
Characteristic of hydrothermal alteration minerals on MT-1 and MT-2 wells, Mataloko, central Flores, East Nusatenggara, Indonesia by using short-wave infrared reflectance spectroscopy
}

\author{
Dany ASWIN ${ }^{1}$ and Fredy NANLOHY ${ }^{1}$
}

\begin{abstract}
Dany Aswin and Fredy NANLOHY (2002) Characteristic of hydrothermal alteration minerals on MT-1 and MT-2 wells, Mataloko, central Flores, East Nusatenggara, Indonesia by using shortwave infrared reflectance spectroscopy. Bull. Geol. Surv, Japan, vol. 53 (2/3), p. 323-328, 4 figs.
\end{abstract}

\begin{abstract}
The short-wave infrared reflectance spectroscopy has been used in a wide range of mineral exploration especially to recognize the alteration minerals related with mineralization. The techniques are also very useful in geothermal exploration especially to determine hydrothermal alteration minerals that are related to the physical and chemical characteristics of the geothermal formation. The spectrally detectable major hydrothermal alterations in wells MT-1 and MT-2 are montmorillonite (+/- zeolite), halloysite, kaolinite, illite and dickite. The over print between the smectite group (montmorillonite) and kaolin group (kaolinite, halloysite and dickite) shows the two fluid conditions in the formation. The smectite group occurs in a non-acid condition while the kaolin group occurs in an acid condition. The trend of decreasing $\mathrm{Al}-\mathrm{OH}$ band wavelength from near the surface to the bottom of the holes reflects to change of state from montmorillonite rich (high Al-OH band absorption) to illite rich (low Al-OH band absorption). Therefore, the Al-OH wavelength data reveal a transition from a smectite dominated zone near the surface to illite dominated zone at the bottom of the well. These features probably also reveal the temperature history of the geothermal formation.
\end{abstract}

\section{Introduction}

The joint research cooperation project between the Indonesian and Japanese Governments to develop small-scale geothermal resources in Mataloko, Ngada District, Flores Island, East Nusatenggara Province - Indonesia commenced in fiscal year 1997 and continues until 2002. The project focused on the surface and subsurface study of the Mataloko geothermal area.

Three shallow wells have been drilled during 19992000. The thermal gradient well MTL-1 was drilled by the Volcanological Survey of Indonesia (VSI) while the exploration well of MT-1 and MT-2 drilled by the cooperation between Indonesia and Japan.

The thermal gradient well of MTL-1 was drilled on 14 October 1999 to a depth of $103.23 \mathrm{~m}$. The 250 $\mathrm{m}$ drilling target can not be reached due to steam suddenly flowing out from down the hole. The first exploration well MT-1 with target about $600 \mathrm{~m}$ situated about $103 \mathrm{~m}$ north of well MTL-1. The well was killed and plugged with cement due to a sudden steam flow and blow out of steam with gases $\left(\mathrm{H}_{2} \mathrm{~S}\right.$ $\& \mathrm{CO}_{2}$ ) around the collar at a total depth $207.26 \mathrm{~m}$.

\footnotetext{
${ }^{1}$ Directorate of Mineral Resources Inventory. Jl. Soekarno-
} Hatta No.444, Bandung, 40254 Indonesia
In order to continue drilling and reach the target, the well MT-1 site shifted to the MT-2 well site that lies $32 \mathrm{~m}$ north of the MT-1 well site. Similar to the MT-1 well, the 600-m drilling target could not be reached. The drilling was stopped at a total depth of $180.02 \mathrm{~m}$ because of the unstable down hole condition as caving of the hole made the drilling operation difficult (Sitorus and Nanlohy, 2000; Sitorus et. al., 2001).

This paper will describe the characteristic of hydrothermal alteration minerals of wells MT-1 and MT-2 by using Short Wave Infrared Reflectance Spectroscopy (SWIR). Portable Infrared Mineral Analyzer (PIMA-II) was used in this study to analyze 68 cutting samples from well MT-1 and 59 cutting sample from well MT-2.

The SWIR detects reflected molecular vibrational energy in the $1.3 \mu \mathrm{m}$ to $2.5 \mu \mathrm{m}$ range of the electromagnetic spectrum. The observed molecules include $\mathrm{OH}, \mathrm{H}_{2} \mathrm{O}, \mathrm{Al}-\mathrm{OH}, \mathrm{Mg}-\mathrm{OH}, \mathrm{Fe}-\mathrm{OH}, \mathrm{CO}_{3}$ and $\mathrm{N}$ $\mathrm{H}_{4}$. These are found as major components of common hydrothermal alteration mineral species such as the kaolinite group (kaolinite, dickite, halloysite), illite (sericite, white micas), smectite group

Keywords: hydrothermal alteration minerals, short-wave infrared reflectance spectroscopy, geothermal field, Mataloko, Flores, Indonesia 
(montmorillonite, nontronite, saponite), carbonate, sulfate and chlorite. Hauff and Cocks (1992) describe that the spectral features of molecules are found at $1.4 \mu \mathrm{m}\left(\mathrm{H}_{2} \mathrm{O}\right.$ plus $\mathrm{OH}$ for clay and sulfates), 2.02 $\mu \mathrm{m}$ and $2.12 \mu \mathrm{m}\left(\mathrm{NH}_{4}\right), 2.2 \mu \mathrm{m}$ (Al-OH), $2.26 \mu \mathrm{m}$ (Fe-OH), $2.3 \mu \mathrm{m}$ (Mg-OH) and $2.3 \mu \mathrm{m}-2.35 \mu \mathrm{m}$ $\left(\mathrm{CO}_{3}\right)$.

\section{Subsurface geology}

From the lithologic column of wells MT-1 and MT-2 (Figs. 1 and 2), it can be seen that the study area is covered by lava and pyroclastics of Quaternary volcanic rocks. The volcanic rocks consist of andesite lava, tuff and tuff breccia. Nanlohy et al. (2002, this volume) describe that the surface of the well is covered by 10 to $15 \mathrm{~m}$ thick of pyroclastic deposit (breccia tuff). The pyroclastics consist of dacitic ash tuff and tuff breccia. From the $15 \mathrm{~m}$ until $100 \mathrm{~m}$ depth, the lithology predominantly consists of andesite. From $100 \mathrm{~m}$ to the bottom of the well, the lithology is mainly pyroclastic deposits (ash tuff and breccia tuff) interbedded with andesite lava.

The rock unit in both wells mostly altered. The intensity of alteration varies from less intense to very intense occurrence. Clay is most prominent hydrothermal alteration mineral found in this area. In some samples, the clay content is up to $70 \%$. The other altered minerals are carbonate, pyrite, anhydrite and silica.

\section{Analysis methods}

Cutting samples were collected from every $3 \mathrm{~m}$ of wells MT-1 and MT-2. The short-wave infrared (SWIR) spectra were measured with an Integrated Spectronics Pty Ltd PIMA-II portable infrared spectrometer. The PIMA-II measures the reflectance of samples across the region of $1.3 \mu \mathrm{m}$ to $2.5 \mu \mathrm{m}$. The spectral data were interpreted by using the PIMA VIEW 3.1 software.

No sample preparation or treatment was carried out prior to spectral measurement. All the data reported in this study are for bulk samples. Also, no special treatment was made for the distinction between mixed layer and mixtures of discrete clay minerals.

\section{Hydrothermal alteration mineral}

\subsection{Montmorillonite}

The statistical data show that montmorillonite is the major clay mineral found in both wells MT-1 and MT-2 (Figs. 1 and 2). The mineral can be found from near the surface to the bottom of the hole. A significant amount of montmorillonite in well MT-1 can be seen at the depths of $50-110 \mathrm{~m}$ and 160 -
$175 \mathrm{~m}$. In well MT-2, a significant amount of montmorillonite can be seen at a depth of $60-85 \mathrm{~m}$ and around $150 \mathrm{~m}$.

\subsection{Halloysite}

The second major clay mineral found in both wells MT-1 and MT-2 is halloysite. The mineral appears almost in all levels of hole. The halloysite in well MT-1 is predominantly found near the surface to a $100 \mathrm{~m}$ depth and from $150 \mathrm{~m}$ to the bottom of well MT-1 while in well MT-2 halloysite is found from near the surface to a $60 \mathrm{~m}$ depth and below $140 \mathrm{~m}$.

\subsection{Kaolinite}

Unlike montmorillonite and halloysite, kaolinite only appears near the surface in both wells MT-1 and MT-2. There are only a few samples that show kaolinite so it is very limited.

\subsection{Dickite}

Dickite is only found as a trace mineral in wells MT-1 and MT-2. The mineral is only found in one sample at a depth of $190 \mathrm{~m}$ in well MT-1 and $143 \mathrm{~m}$ in well MT-2.

\subsection{Illite.}

Similar to dickite, illite is also found only in a few samples in both wells MT-1 and MT-2. The minerals also occur only at the lower level of the holes.

\section{Discussion}

In general, there are three groups of clay minerals in both wells MT-1 and MT-2: the kaolinite/ halloysite group at the top of the hole, smectite group (+/- zeolite) in the middle and kaolin (halloysite+dickite) +/- illite at the bottom.

The predominance of montmorillonite in the samples probably coexisted with zeolite minerals, although the spectrum of zeolite minerals is very similar with the spectrum of montmorillonite. This is also supported by XRD and microscopic study of those samples by Nasution (2001; personal communication) as wairakite has been found in several samples at the lower part of the holes.

The chemical change in the fluids can be seen from the overprint between montmorillonite and kaolin group (kaolinite, dickite and halloysite) because montmorillonite occurs in a non-acidic condition while the kaolin group occurs in an acidic condition. The appearance of dickite at the lower part of the well shows that the condition of formation is acidic and temperature increases downward.

Figures 3 and 4 clearly show that the Al-OH absorption in both drill holes decreases downward. 


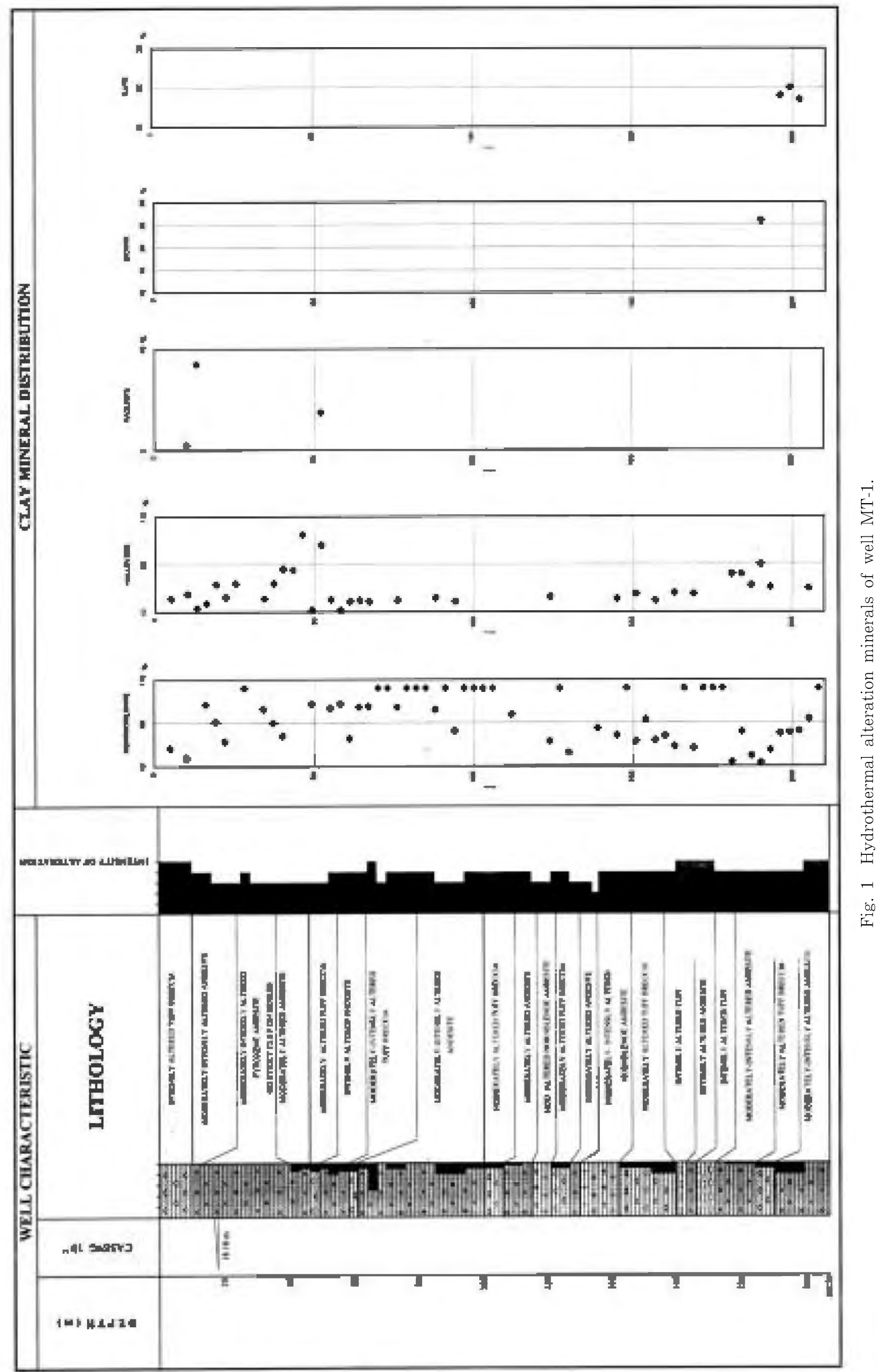




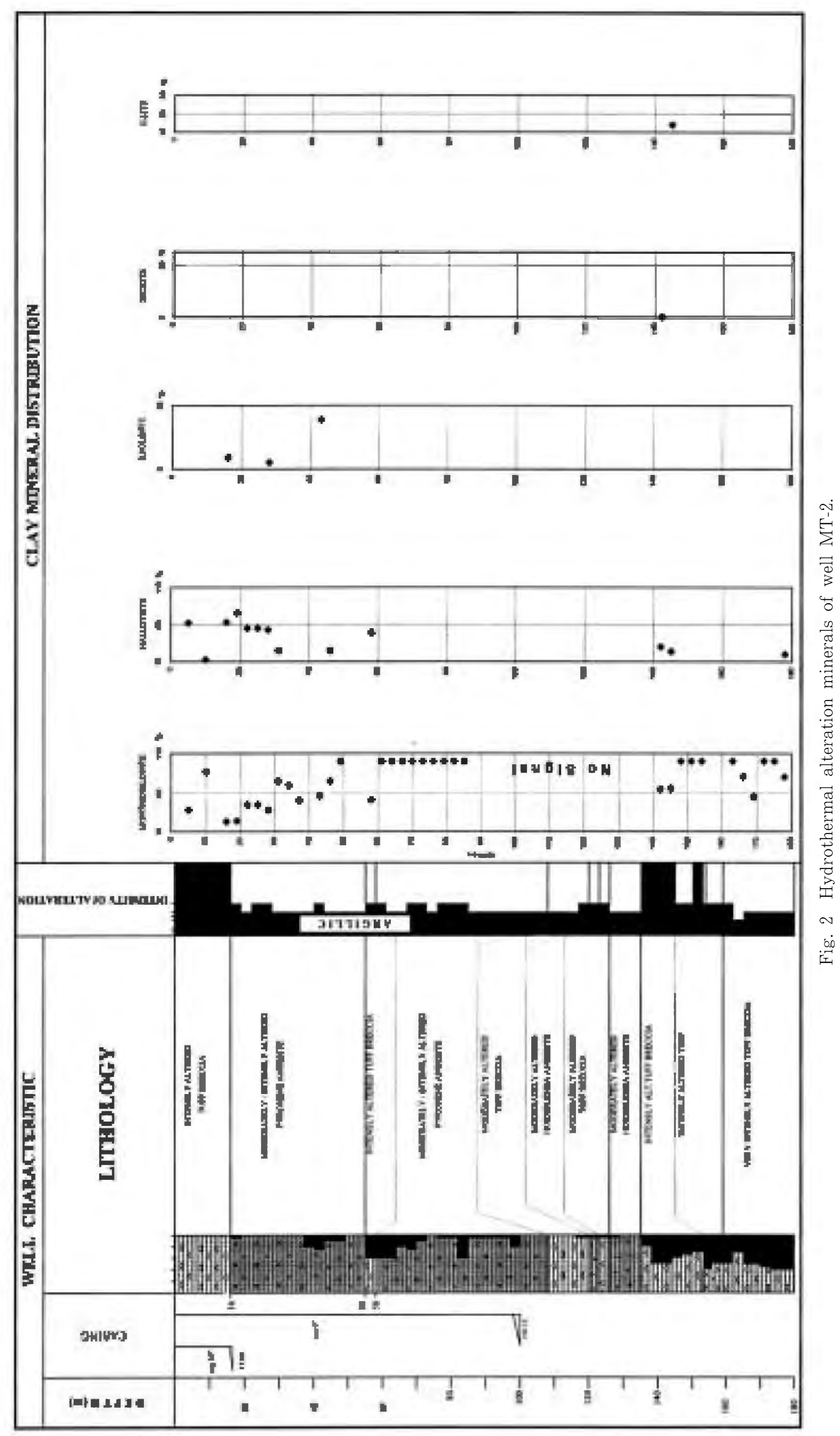


MT-1

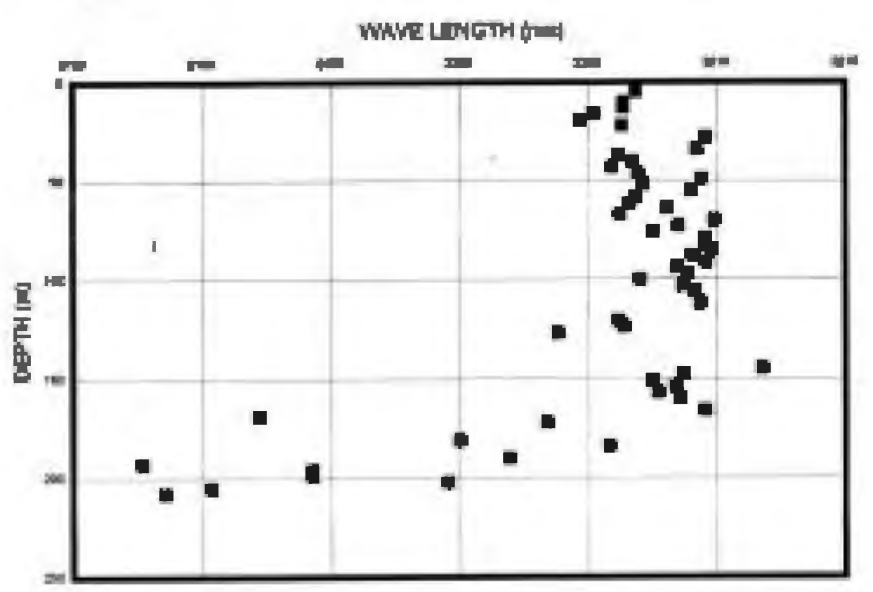

Fig. 3 Al-OH absorption of well MT-1.

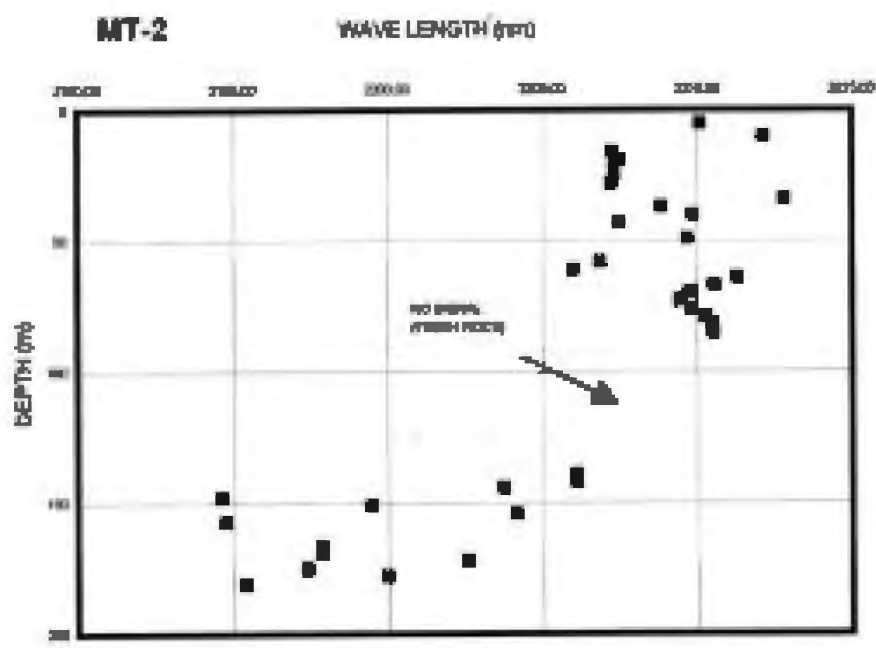

Fig. 4 Al-OH absorption of well MT-2.

According to Yang and Browne (1999), the trend of decreasing $\mathrm{Al}-\mathrm{OH}$ band wavelength from near surface to the bottom of the hole reflects the downward change from montmorillonite (Al-OH band near $2208 \mathrm{~nm}$ ) to illite (Al-OH band near $2198 \mathrm{~nm}$ ).

\section{Conclusion}

The hydrothermal alteration minerals in wells MT-1 and MT-2 are dominated by low temperature alteration minerals (argillite) with an overprint between the acidic condition and non-acidic condition.

The general distribution of clay minerals in wells MT-1 and MT-2 can be divided into three zones. They are the kaolin (halloysite) zone at the surface, montmorilonite (+/- zeolite) zone at the middle and kaolin (+/- illite) zone at the bottom.

The Al-OH wavelength data reveal a transition from smectite rich (montmorillonite) nature near the surface to illite rich nature at the bottom. Therefore, SWIR can be used as a tool in geothermal exploration to determine the hydrothermal alteration minerals especially clay minerals.

Acknowledgements: We are grateful to the Directorate of Mineral Resources Inventory to allow us to use PIMA-II and publish this paper. We appreciate to Mr. Prima who assisted the analysis of samples and to Mr. Fahmi for drawing the figures. Many thanks also to Dr. Muraoka for supporting us to write and submit this paper.

\section{References}

Hauff, P. and Cocks, T. (1992) Short wave infrared spectroscopy techniques applied to exploration, emphasis on alteration mineralogy. In: Clay Mineralogy in Exploration and Exploration Geochemistry, EGRU, James Cook University, 72-74.

Nanlohy, F., Sitorus, K., Kasbani, Dwipa, S. and Simanjuntak, J. (2002) Subsuface geology of the Mataloko geothermal field deduced from MTL-1, MT-1 and MT-2 wells, central Flores, East Nusa Tenggara, Indonesia. Bull. Geol. Surv. Japan, 53, 329-336.

Sitorus, K. and Nanlohy, F. (2000) Subsurface geology of the Mataloko shallow well (MTL-01), the Mataloko geothermal field, Ngada - NTT, Flores - Indonesia. In: Abstracts of IAVCEI General Assembly 2000, Bali Indonesia, 276.

Sitorus, K., Nanlohy, F. and Simanjuntak, J. (2001) Drilling activity in the Mataloko geothermal field, Ngada, NTT, Flores, Indonesia. Proceeding of the 5th INAGA Annual Scientific Conference and Exhibitions, Yogyakarta, Volcanological Survey of Indonesia, 6p.

Yang, K. and Browne, P.R.L. (1999) Characteristic hydrothermal alteration of BroadlandsOhaaki geothermal system, New Zealand, using short-wave infrared reflectance spectroscopy. Exploration and Mining Research News, 11, 11-12.

Received October 5, 2001

Accepted February 21, 2002 


\title{
短波長赤外線反射スペクトルを用いたインドネシア， ヌサテンガラ東部 フローレス島中央部マタロコの MT - 1 および MT - 2 井における熱水変質鉱物の特徵
}

\section{Dany AsWIN • Fredy NANLOHY}

\begin{abstract}
要旨
短波長赤外線反射スペクトルは，鉱物の調査，特に鉱化作用に関連する変質鉱物の認定に広く用いら れている。本手法は地熱調査にも，特に地熱系の物理・化学的特性に関連する熱水变質鉱物の決定に， 極めて有用である．MT - 1 および MT - 2 井において検出された主な熱水変質鉱物は，モンモリロナイ 卜（土沸石），八ロイサイト，カオリナイト，イライト，ディッカイトである。スメクタイト・グルー プ（モンモリロナイト）とカオリン・グループ（カオリナイト，八ロイサイト，ディッカイト）が重なっ ていることは，2 種類の流体環境があったことを示している．スメクタイト・グループは非酸性環境で 生成するのに対し，カオリン・グループは酸性環境で生成する。 Al-OH バンドの波長は地表付近から 坑底に向かって減少傾向を示し，モンモリロナイトに富む（Al-OH バンドの吸収が高い）状態からイ ライトに富む（Al-OH バンドの吸収が低い）状態へと变化することを反映している，すなわち， Al- $\mathrm{OH}$ バンド波長のデータにより, 地表付近のスメクタイト卓越ゾーンから坑底のイライト卓越ゾーンヘ移化 することが明らかとなった。また，このことから地熱系の熱史も明らかになると考えられる。
\end{abstract}

(要旨翻訳：水垣桂子 (地圏資源環境研究部門)) 